lobes. Pediatr Neurol Jan 2007;36:13-16). (Respond: Satoshi Yoshinari MD, Division of Neurology, Saitama Children's Medical Center, 2100 Magome, Iwatsuki-ku, Saitama-city, Saitama 339-8551, Japan).

COMMENT. HHV-6 infection is most commonly associated with febrile seizures; it accounts for one-third of all first-time cases in children up to 2 years of age (Hall CB et al. $\mathbf{N}$ Engl J Med 1994;331:432-438). These authors detected HHV-6 DNA by PCR in 2 of 7 CSF samples of HHV-6 associated febrile seizure patients. In 9 patients with acute infantile encephalopathy predominantly affecting the frontal lobes, the associated infection was influenza type A in 3, HHV-6 in 2, measles in 1, and upper respiratory viral illness unspecified in 3. (Yamanouchi $\mathrm{H}$ et al. Pediatr Neurol 2006;34:93-100; Ped Neur Briefs March 2006;20:20-21). Serial MRIs showed atrophic changes in both frontal lobes, and PET studies revealed decreased perfusion in frontal lobes, with normalization at $7^{\text {th }}$ to $38^{\text {th }}$ month after onset. Prolonged impairment of consciousness after convulsions, and behavioral sequelae were consistent with an encephalopathy. These cases are unique in the predilection for the frontal lobes, but they are not HHV-6 specific.

\title{
HERPES SIMPLEX VIRUS INFECTIONS IN PRETERM INFANTS
}

A retrospective review of herpes simplex virus (HSV) infections within the first 30 days after birth in infants born at $<37$ weeks was conducted at Johns Hopkins University School of Medicine, Baltimore, MD. Ten preterm singletons and a set of twins were infected with HSV-2 and presented with either disseminated disease $(n=9)$ or encephalitis $(n=3)$. All infants with disseminated disease died, whereas the 3 with encephalitis survived. All developed respiratory distress, and viral cultures were positive. Ten were treated with acyclovir within 48 hours of onset; 2 of 3 treated with high-dose acyclovir $(60 \mathrm{mg} / \mathrm{kg} /$ day $)$ survived. (O'Riordan DP, Golden WC, Aucott SW. Herpes simplex virus infections in preterm infants. Pediatrics Dec 2006;118:e1612-e1620).

COMMENT. HSV infections in preterm infants present with respiratory distress and a high incidence of disseminated disease. In this population, response to acyclovir is poor and mortality high. The AAP Red Book (2006;p365) states that most neonates treated for HHV encephalitis survive, but most suffer substantial neurologic sequelae. Approx $25 \%$ of neonates with disseminated disease die despite antiviral therapy.

\section{NEUROMUSCULAR DISORDERS}

\section{CSF MARKERS IN GUILLAIN-BARRE SYNDROME}

A positive 14-3-3 protein assay of CSF was observed in 29 of 38 patients with GBS and in 4 with motor neuron disease and other neuropathies studied at Universities of Milan and Verona, Italy. The protein is detected as early as 12 to 48 hours after disease onset and represents a useful biological marker in GBS. (Bersano A, Fiorini M, Allaria S et al. Detection of CSF 14-3-3 protein in Guillain-Barre syndrome. Neurology Dec 2006;67:22112216). (Respond: Dr S Monaco; e-mail: salvatore.monaco@univr.it). 